Monika Paszke*

\title{
ROLA ROLNICTWA WSPIERANEGO PRZEZ SPOLECZNOŚĆ W ROZWOJU ZRÓWNOWAŻONYM
}

\author{
THE ROLE OF COMMUNITY-SUPPORTED AGRICULTURE \\ IN SUSTAINABLE DEVELOPMENT
}

\begin{abstract}
The main aim of the research is to present the essence Community-supported agriculture (CSA) concept by illustrating the application of this idea in sustainable development in rural areas in Poland. The article focuses on pointing out the determinants for the development of CSA and gives some examples of using this concept in other countries. Based on the analyzed literature of the subject, both Polish and foreign, the basic assumptions and objectives of the concept are presented as well as the barriers of development and the expected results. CSA is a relatively new concept in Poland. However, it's implementation may contribute to solving the problem of green jobs and dynamic development of rural areas while preserving the environment.
\end{abstract}

Keywords: community-supported agriculture, sustainable development, green job, green economy

JEL classification: Q13 wp.pl

*Uniwersytet Ekonomiczny w Poznaniu, SKN Gospodarki Żywnościowej, monikapaszke@ 


\section{Wprowadzenie}

Współczesny biznes napotyka wiele problemów natury etycznej, ekonomicznej, społecznej oraz ekologicznej. Wyzwania te nabierają szczególnego znaczenia w czasach, gdy powszechnie przyjmowanym paradygmatem myślenia o przyszłości jest rozwój zrównoważony. Szybki wzrost gospodarczy podniósł dobrobyt państw rozwiniętych, ale także przyczynił się do pogorszenia stanu środowiska naturalnego. Zdefiniowanie terminu rozwoju zrównoważonego rodzi dyskusje i z biegiem czasu można zauważyć stopniowe poszerzanie zakresu problematyki tej koncepcji1 ${ }^{1}$. B. Oleszko-Kurzyna zauważa jednak wspólne cechy dla wszystkich definicji ${ }^{2}$. Pojawia się przede wszystkim nawiązanie do zapewnienia takich samych szans zaspokojenia potrzeb przyszłym pokoleniom, jakie ma współczesna generacja $^{3}$. Istotą idei rozwoju zrównoważonego jest sposób prowadzenia działalności gospodarczej, organizacji społeczeństwa i wykorzystania środowiska jako próby pogodzenia aspiracji człowieka z zachowaniem zasobów naturalnych dla przyszłych pokoleń. Natomiast według A. Wosia zrównoważony rozwój obszarów wiejskich jest nie tylko obowiązkiem moralnym, ale także koniecznością ekonomiczną ${ }^{4}$.

Ogólnoświatowy kryzys gospodarczy, a także świadomość ograniczeń dotychczasowej formy działalności biznesowej przyczyniły się do przejścia od brown economy do green economy. Unia Europejska potwierdziła to na przykład w Siódmym programie działań środowiskowych do 2020 „Dobrze żyć w granicach naszej planety". Dokument ten porusza temat zagrożeń naszej planety, sugerując zmiany strukturalne, które prowadzą do zielonej gospodarki. Zmiany te obejmują także strefę społeczną, a mianowicie zielone miejsca pracy, nazwane potocznie zielonymi kołnierzykami ${ }^{5}$.

Zielone miejsca pracy coraz częściej znajdują swoje zastosowanie w wielu branżach, również w rolnictwie. Zielone kołnierzyki przyczyniają się do zmniejszenia konsumpcji energii, zasobów naturalnych, ograniczają ilość zanieczyszczeń, ochraniają ekosystem oraz przyczyniają się do przywrócenia go do stanu pierwotnego ${ }^{6}$. B. Kryk definiuje je jako wszystkie miejsca pracy, które wywierają niższy niż przeciętnie wpływ na środowisko naturalne ${ }^{7}$. Zielone miejsca pra-

${ }^{1}$ D. Żmija, Zrównoważony rozwój rolnictwa i obszarów wiejskich w Polsce, „Polityka Gospodarcza w Okresie Transformacji i Kryzysu” 2014, nr 166, s. 149.

${ }^{2}$ B. Oleszko-Kurzyna, Rozwój zrównoważony rolnictwa wobec wymagań UE w zakresie ochrony środowiska, „Zeszyty Naukowe SGGW w Warszawie. Problemy Rolnictwa Światowego” 2008, t. 98 , z. 4, s. 326-336.

${ }^{3}$ B. Kryk, Relacje ekonomii społecznej z koncepcja zrównoważonego rozwoju, „Ekonomia i Środowisko" 2012, nr 3(43), s. 213.

${ }^{4}$ Za: ibidem.

${ }^{5}$ B. Kryk, Czas na zielone kotnierzyki, „Ekonomia i Środowisko” 2012, nr 3(50), s. 11.

${ }^{6}$ D. Szyja za: M. Rutkowska-Podołowska, Ł. Popławski, Rolnictwo a zielone miejsca pracy, „Studia i Prace WNEiZ US” 2016, nr 44/3, s. 202.

${ }^{7}$ B. Kryk, Czas na zielone kotnierzyki..., s. 12-13. 
cy to jedno z głównych założeń zielonej gospodarki i rozwoju zrównoważonego, a koncepcją wspomagającą ich rozwój jest Rolnictwo Wspierane przez Społeczność (RWS).

RWS jest inicjatywą ugruntowaną na rozwoju zrównoważonym, polegającą na współpracy rolników i konsumentów, opartej na wsparciu i bezpośrednim kontakcie tych grup ${ }^{8}$. Celem artykułu jest ukazanie RWS jako szansy dla rozwoju zielonych miejsc pracy oraz rozwoju zrównoważonego.

W artykule przedstawiono podstawowe zasady, cele, zagrożenia oraz perspektywy rozwoju koncepcji RWS. W pracy została wykorzystana metoda badań wtórnych - dokonano krytycznej analizy literatury przedmiotu: polskiej i zagranicznej, zarówno artykułów naukowych, wywiadów, jak i stron internetowych związanych $\mathrm{z}$ zagadnieniem RWS. Wyniki analizy przedstawiono w formie opisowej.

\section{Uwarunkowania rozwoju Rolnictwa Wspieranego przez Społeczność}

W modelu Rolnictwa Wspieranego przez Społeczność na początku sezonu odbiorcy towarów płacą rolnikom ustaloną kwotę. Głównym celem nie jest wytworzenie taniej żywności, ale zapewnienie korzystnej i sprawiedliwej ceny ustalanej przez obie strony. Pozwala to na uniknięcie zaciągania pożyczek przez rolnika, ponieważ zna on swój budżet i prowadzi działalność niezależnie od cen rynkowych czy urodzaju. Natomiast konsumenci zyskują dostęp do regularnie dostarczanej, świeżej i zdrowej żywności po przystępnych cenach ${ }^{9}$. Ten alternatywny model współpracy opiera się na pięciu zasadach:

1) partnerstwie, przez umowę pisemną lub ustną;

2) solidarności, gdyż obie strony ponoszą ryzyko związane z uprawą (konsumenci wspierają rolników podczas nieurodzaju, a ci nagradzają swoich klientów w okresach nadwyżki);

3) wspieraniu lokalnej gospodarki;

4) pomocy w rozwoju gospodarstw, które utrzymują zróżnicowany model upraw;

5) angażowaniu lokalnej społeczności ${ }^{10}$.

${ }^{8}$ J. Olszewska, P. Trzaskowski, Rolnictwo Wspierane przez Społeczność, partnerstwo między rolnikami a konsumentami, IGO, Warszawa 2014, s. 4.

${ }^{9}$ J. Radziewicz, Rolnictwo Wspierane przez Społeczność - zdrowa żywność od rolnika, „Rolniczy Magazyn Elektroniczny" 2016, http://rme.cbr.net.pl/index.php/wiadomosci-rolnicze/573-archiwum-rme/marzec-kwiecien-nr-72/wiadomosci-rolnicze/870-rolnictwo-wspierane-przez-spolecznosc-rws-zdrowa-zywnosc-prosto-od-rolnika (dostęp: 8.05.2017).

${ }^{10}$ J. Olszewska, P. Trzaskowski, op. cit., s. 6. 
Ze strony prawnej współpraca ta przybiera postać umowy sprzedaży bezpośredniej produktów wytworzonych przez rolnika, co gwarantuje brak opodatkowania obowiązującego dla tego typu sprzedaży $y^{11}$.

Koncepcja RWS jest szansą nie tylko dla producentów rolnych i konsumentów, ale przyczynia się również do realizacji celów ekologicznych. Współcześnie kontrolę nad rynkiem żywnościowym przejęły bowiem korporacje międzynarodowe, które często szukają dróg do szybkiego i spektakularnego sukcesu kosztem równowagi ekologicznej. Prowadzi to do zaniku bioróżnorodności i rozwoju monokultur, w coraz gorszej sytuacji znajdują się także rodzinne gospodarstwa rolne $^{12}$. Taka sytuacja jest zagrożeniem dla bezpieczeństwa żywności oraz bezpieczeństwa ekologicznego.

Jedną z najszybciej rozwijających się gałęzi rolnictwa na świecie (także w Polsce) jest rolnictwo ekologiczne. Od 2004 roku, a więc od momentu przystąpienia Polski do Unii Europejskiej, liczba gospodarstw ekologicznych wzrosła z 3760 do 23000 w 2015 roku (od około 82000 do około 550000 hektarów powierzchni $)^{13}$. Najwięcej tego typu gospodarstw znajduje się w województwach: warmińsko-mazurskim (3477) i zachodniopomorskim (2843) oraz podlaskim (2815) ${ }^{14}$. Bezpośredni zakup produktów u producentów wspierałby więc dalszy rozwój tej gałęzi rolnictwa i przyczyniłby się do poprawy sytuacji ekonomicznej rolników ekologicznych.

W swojej pracy C. Brown i S. Miller na podstawie funkcjonowania RWS w Stanach Zjednoczonych przekonują, że kluczem do odbudowy lokalnych systemów żywności i rolnictwa jest właśnie współpraca rolników i mieszkańców ${ }^{15}$. Przynosi to określone rezultaty, między innymi zintensyfikowanie lokalnych działań, nawiązywanie kontaktów, zwiększenie różnorodności produktów rolno-żywnościowych oraz wiedzy o nich, a co szczególnie ważne - zapewnia dodatkowe miejsca pracy.

Cele RWS wpisują się w główne założenia rozwoju UE. Podstawą rozwoju rolnictwa i obszarów wiejskich w Unii Europejskiej jest wspólna polityka rolna, a jej celem trwały rozwój nie tylko gospodarczy, ale także ekologiczny i społeczny. Odejście od gospodarki planowanej, a następnie akcesja Polski do UE w 2004 roku zmieniły podejście do ochrony środowiska. Wspólna Polityka Rolna ukierunkowuje bowiem rolnictwo europejskie na rozwój zrównoważony. Reorganizacja systemu wspierania,

${ }^{11}$ C. Ciobanu, P. Trzaskowski, Rolnictwo Wspierane przez Społeczność. Budując sojusz między miastem a wsia, 2017, https://cohabitat.net/blog/rolnictwo-wspierane-przez-spolecznosc-budujac-sojusz-miedzy-miastem-i-wsia (dostęp: 9.05.2017).

12 J. Olszewska, P. Trzaskowski, op. cit., s. 7-8.

${ }^{13}$ J. Barłowska, A. Wolanciuk, J. Idec, Rolnictwo ekologiczne w Polsce na tle Unii Europejskiej i świata, „Przegląd Hodowlany” 2017, nr 2.

${ }^{14}$ Stan na rok 2015.

${ }^{15} \mathrm{C}$. Brown, S. Miller, The Impact of local: a review of research on farmers markets and community supported agriculture, „American Journal of Agricultural Economics” 2008, vol. 90, issue 5, s. 1300. 
polegająca na współfinansowaniu inicjatyw w ramach ochrony środowiska i zrównoważonego rozwoju, ma na celu pobudzenie i zintensyfikowanie aktywności podmiotów gospodarczych na terenie Wspólnoty. Zmieniły się także wymagania wobec rolnictwa i jego podmiotów: oczekuje się, aby obok samej produkcji, istotne stały się jakość żywności oraz rozwój obszarów wiejskich i ochrona środowiska ${ }^{16}$.

W obecnej Strategii zrównoważonego rozwoju wsi, rolnictwa i rybactwa na lata 2012-2020 za główny cel obrano wszystkie wymienione wyżej aspekty, tj. poprawę życia na obszarach wiejskich oraz efektywne wykorzystanie ich zasobów, a wszystko to w ramach zrównoważonego rozwoju kraju ${ }^{17}$. Unia Europejska stara się tym samym zmniejszyć bezrobocie na obszarach wiejskich, bez konieczności migracji mieszkańców wsi do miast. Podejmowane działania mają doprowadzić do poprawy warunków życia, wzrostu zamożności, a co za tym idzie - także poprawy jakości infrastruktury. Inną przyczyną dużego zainteresowania rolnictwem jest potrzeba zapewnienia bezpieczeństwa żywności. Podnoszenie świadomości i wiedzy producentów żywności, a także wzmocnienie poczucia odpowiedzialności przyczynia się do poprawy jakości produktów rolno-spożywczych. Dodatkowo wsparcie rozwoju zrównoważonego i rozwoju obszarów wiejskich skutkuje bezpośrednio ochroną środowiska i ułatwia adaptację do zmian klimatu ${ }^{18}$.

Kolejnym argumentem przemawiającym za Rolnictwem Wspieranym przez Społeczność są prozdrowotne oczekiwania konsumentów dotyczące produktów oraz troska o codziennie spożywane posiłki. Na popularności zyskuje nie tylko aktywność sportowa czy wspomniane zdrowe odżywianie, ale również dbałość o środowisko. Przejawia się to w nowych trendach, które pojawiają się na rynku. Konsumenci stają się świadomi tego, że każdy zakupiony produkt wiąże się z dodatkowymi kosztami, takimi jak degradacja środowiska, niesprawiedliwe płace czy też narażanie zdrowia zarówno przez wytwórców, jak i konsumentów ${ }^{19}$. W związku z tym na rynku pojawiła się alternatywa dla tradycyjnego handlu, jaką jest sprawiedliwy handel (Fair Trade). Ma on na celu wsparcie współpracy, sprawiedliwy i zrównoważony łańcuch dostaw, a także promuje aktywne zaangażowanie konsumentów. Do podstawowych zasad Fair Trade należy nawiązywanie długoterminowych umów między producentami i kupcami, a także gwarancja odpowiednio wysokiej ceny ${ }^{20}$, Rolnictwo Wspierane przez Społeczność spełnia więc warunki sprawiedliwego handlu.

${ }^{16}$ B. Oleszko-Kurzyna, op. cit.,

${ }^{17}$ Ustawa z dnia 6 grudnia 2006 r. o zasadach prowadzenia polityki rozwoju (Dz.U. z 2009 r. $\mathrm{Nr} 84$, poz. 712 z późn. zm.).

${ }^{18}$ D. Żmija, op. cit., s. $153-155$.

${ }^{19}$ K. Wasilik, Idea Fair Trade. W kierunku odpowiedzialnej konsumpcji, „Zeszyty Naukowe Uniwersytetu Szczecińskiego. Problemy Zarządzania, Finansów i Marketingu" 2015, nr 38, s. $101-108$.

${ }^{20}$ Głównym celem Fair Trade jest zwiększenie równości w handlu międzynarodowym przez wsparcie producentów, godziwe wynagrodzenie i zwiększenie świadomości wśród konsumentów. 
Dodatkowo na rynku pojawiają się także inne trendy konsumpcyjne wspierające RWS. Jednym z najbardziej popularnych jest LOHAS (Lifestyle of Health and Sustainability). Zakłada on odejście od zachłannej konsumpcji na rzecz zdrowego stylu życia i poszanowania środowiska. Trend ten w swojej idei zachęca do poszukiwania punktu równowagi między tym, co zdrowe, a tym, co przyjazne środowisku ${ }^{21}$. Innym prozdrowotnym trendem jest tzw. locavore, który polega na świadomym wyborze zdrowej i lokalnej żywności. Główna zasada tej idei brzmi: „,im mniej kilometrów musi pokonać produkt, zanim trafi na nasze stoły, tym lepiej" ${ }^{22}$. Wszechobecna dbałość o ochronę środowiska i żywności, a także działania mające na celu polepszenie sytuacji na obszarach wiejskich potwierdzają, że Rolnictwo Wspierane przez Społeczność jest z założenia dobrą drogą do osiągnięcia zamierzonych celów.

\section{Sytuacja Rolnictwa Wspieranego przez Społeczność na świecie i w Polsce}

Idea Rolnictwa Wspieranego przez Społeczność narodziła się w latach siedemdziesiątych XX wieku w Japonii jako odpowiedź na falę urbanizacji oraz zwiększenia środków chemicznych wykorzystywanych do produkcji żywności. W związku z pogarszającą się jakością żywności grupa matek nawiązała stałą współpracę z lokalnymi rolnikami. Po czteroletniej kooperacji pomysł ten przeobraził się w całosezonowe, płatne z góry kontrakty. Dziś takich grup jest Japonii ponad pięćset ${ }^{23}$. W latach osiemdziesiątych pomysł ten został wykorzystany w USA. Dziś szacuje się, że funkcjonuje tam około tysiąca grup, a tylko w samym Nowym Jorku w ramach Commuinty Supported Agriculture (CSA) z lokalnymi rolnikami współpracuje 16000 konsumentów ${ }^{24}$. Najczęściej wspierane w tym zakresie są małe i średnie gospodarstwa rolne, które pracują z okolicznymi grupami odbiorców. Tak duże zainteresowanie CSA sprawiło, że rozwinęło się tam wiele form tej kooperacji. Można spotkać się z klasyczną formą ,abonamentu”, a także wymianą towarów $\mathrm{w}$ zamian za przepracowane godziny $\mathrm{w}$ danym gospodarstwie ${ }^{25}$. Co ciekawe, pojawiła się także opcja ustalenia ceny produktów w zależności od dochodów rodziny (dotyczy to głównie osób uboższych). W USA wykształciła się również inna forma współpracy, której podstawy pochodzą z idei RWS, tzw. consumer-led CSA.

${ }^{21}$ M. Schulz, Oczekiwania konsumentów na rynku produktów prozdrowotnych i przyjaznych dla środowiska, „Nierówności Społeczne a Wzrost Gospodarczy” 2016, nr 45, s. 122.

${ }^{22}$ Ulica Ekologiczna, Locavore - myśl globalnie, jedz lokalnie, 2014, http://ulicaekologiczna. $\mathrm{pl} /$ kuchnia/locavore-mysl-globalnie-jedz-lokalnie (dostęp: 18.06.2017).

${ }^{23} \mathrm{~J}$. Radziewicz, op. cit.,

${ }^{24}$ Amerykański odpowiednik Rolnictwa Wspieranego przez Społeczność.

${ }^{25}$ J. Olszewska, P. Trzaskowski, op. cit., s. 11. 
Działa on na zasadzie spółdzielczości: grupa odbiorców, chcąca podjąć się założenia upraw, uzyskuje dostęp do ziemi, a następnie prowadzi działalność - inwestuje, planuje, zatrudnia osoby, a wszystko przy sprawiedliwym podziale głosów, dóbr i cen. Wiąże się to z większą niż w przypadku zwykłego CSA determinacją, zaangażowaniem i wiedzą ${ }^{26}$.

S.M. Schnell zbadał cechy charakterystyczne amerykańskich regionów, w których CSA cieszy się największą popularnością. Taką formą współpracy najczęściej zainteresowani są mieszkańcy metropolii, regionów o wysokim wskaźniku urbanizacji, a także obszarów o stosunkowo wysokiej liczbie małych gospodarstw rolnych. Idea CSA częściej popierana jest także przez osoby z wyższym wykształceniem oraz osoby stosunkowo bogate ${ }^{27}$. Okazuje się, że zróżnicowanie występuje również w podziale na pochodzenie etniczne - koncepcja ta jest najmniej popularna wśród czarnoskórych mieszkańców USA, co autor tłumaczy ich przeciętnie niższymi zarobkami. Podział pojawił się także między regionami politycznymi: idea CSA rzadziej jest stosowana w dwóch konserwatywnych regionach - na Południu oraz na Wielkich Równinach. Poza tym RWS funkcjonuje także między innymi w Malezji, Indiach, Chinach (działa tu około 800 RWS-ów), Australii, Maroko, Brazylii.

W Europie idea RWS powstała w związku z kursami Rudolfa Steinera (odbywały się one w 1924 roku koło Wrocławia), który jest ojcem rolnictwa biodynamicznego, będącego poprzednikiem współczesnego ekologicznego rolnictwa ${ }^{28}$. Obecnie z tą formą współpracy można się spotkać w 20 europejskich państwach: Austrii, Belgii, Chorwacji, Czechach, Finlandii, Francji, Hiszpanii, Holandii, Irlandii, Niemczech, Norwegii, Polsce, Rumunii, Serbii, Słowacji, Szwajcarii, Szwecji, Wielkiej Brytanii oraz na Węgrzech i we Włoszech. Liczba RWS-ów oscyluje w granicach 28 tysięcy i zapewnia żywność dla około 500000 konsumentów ${ }^{29}$. We Francji AMAP (odpowiednik RWS) wspiera dochody tysiąca gospodarstw rolnych, które dostarczają swoje produkty do około 300000 konsumentów $^{30}$. Początki tej formy współpracy we Francji są datowane na rok 2001. W Prowansji, gdzie koncepcja cieszy się największą popularnością, małe targowiska z lokalną żywnością są codziennością dla wielu mieszkańców. Mimo to okoliczne gospodarstwa mają problemy z płynnością finansową. AMAP stał się dla nich alternatywnym rozwiązaniem i obecnie zrzesza kilka tysięcy gospodarstw i okolicznych konsumentów.

${ }^{26}$ C. Ciobanu, P. Trzaskowski, op. cit.,

${ }^{27}$ S.M. Schnell, Food with a Farmer's Face: Community-Supported Agriculture in the United States, „Geographical Review” 2007, vol. 97, nr 4, s. 554-557.

${ }^{28}$ Austriacki filozof, twórca antropozofii, był mistykiem badającym spuściznę Goethego, żył w latach 1861-1925.

${ }^{29}$ M. Jarocka, J. Olszewska, Żywność, ludzie, środowisko, IGO, Warszawa 2016, s. 14-15.

${ }^{30}$ Stowarzyszenie na rzecz Wspierania Rolnictwa Chłopskiego. 
Innym narodem, który próbuje przenieść RWS na swój rynek, są Czesi, jednak jest to mniejsza skala działania niż w wyżej wymienionych krajach. Zazwyczaj współpraca polega na opłaceniu zakupu z góry przez konsumentów, dodatkowo spoczywa na nich odpowiedzialność w kwestii odbioru towaru. Współpracę w ramach RWS nawiązuje się najczęściej z certyfikowanymi gospodarstwami ekologicznymi. Na Węgrzech natomiast tylko kilka gospodarstw prowadzi działalność opartą na RWS, a w ich promocję zaangażowane jest Stowarzyszenie Świadomych Konsumentów. W kraju tym działają także tzw. grupy zakupowe, będące pośrednikami między konsumentami a rolnikami, u których robi się zakupy. Pierwsze RWS, które powstały w 1998 roku, zakończyły szybko swoją działalność ze względu na błędnie skalkulowane koszty oraz brak akceptacji ze strony konsumentów zawartości paczek produktów ustalonych z góry. Obecne RWS stają się coraz popularniejsze i liczba ich członków wzrasta. Starają się oni rezygnować ze środków chemicznych w swoich uprawach lub stosować tylko metody ekologiczne ${ }^{31}$.

W Polsce pierwszy RWS pojawił się w roku 2012 i został założony przez członków Warszawskiej Kooperatywy Społecznej przy pomocy doświadczonej osoby z Czech. RWS Świerże-Panki działał na obszarze województwa mazowieckiego i sezon rozpoczynał od spotkania społeczności i omówienia szczegółów dostawy, typów produktów oraz analizy kosztów. Następnie spisywano umowy cywilno-prawne między konsumentami a rolnikami. W roku 2014 RWS zakończył swoją działalność, jednakże pomysł ten został wykorzystany przez inne podmioty ${ }^{32}$. Obecnie w ramach RWS swoje usługi świadczy sześć gospodarstw rolnych. Jednym z nich jest RWS Dobrzyń nad Wisłą, który konsumentów z Torunia i Warszawy zaopatruje głównie w warzywa, dodatkowo rolnicy swoją ziemię uprawiają zgodnie z wytycznymi rozwoju zrównoważonego. Innym gospodarstwem jest RWS Dobrodziej, który swoje paczki, zawierające nie tylko warzywa, ale także przetwory, dostarcza do Poznania i Szczecina. Dodatkowym atutem jest posiadany przez to gospodarstwo certyfikat eko, który potwierdza odpowiednią jakość produkowanej żywności. Natomiast RWS Gut-u-Anki dostarcza paczki zawierające nabiał, mięso i jajka do mieszkańców Gutowa i okolic. Pozostałe RWS-y działające na terenie Polski to RWS Wojciechówka, RWS Eko farma u Piotra, RWS Pani Wandy ${ }^{33}$.

${ }^{31}$ J. Olszewska, P. Trzaskowski, op. cit., s. 11.

${ }^{32}$ Polska Zielona Sieć, Alternatywne systemy żywnościowe: Rolnictwo Wspierane przez Społeczność, 2014, http://dlaklimatu.pl/alternatywne-systemy-zywnosciowe-rolnictwo-wspierane-przez-spolecznosc/ (dostęp: 10.05.2017).

${ }^{33}$ Wspieraj Rolnictwo, RWS-y w Polsce, 2017, http://www.wspierajrolnictwo.pl/rwsy-w-polsce (dostęp: 5.05.2017). 


\section{Bariery i perspektywy rozwoju RWS w Polsce}

Skąd rosnąca popularność RSW? Dla konsumentów zaletą jest nie tylko możliwość kontrolowania żywności (mają oni prawo doglądać upraw, jeśli wyrażą taką chęć), ale również wyeliminowanie kosztów, które podrażają produkt finalny w sklepach (np. opłaty za pośrednictwo, opakowanie). RWS-y mogą także chronić małe gospodarstwa przed bankructwem. Zauważalny w ostatnim czasie spadek liczby lokalnych sklepów i bazarów przyczynił się do ograniczenia, a nawet całkowitego zaniku przychodów okolicznych rolników, którzy byli bezpośrednimi dostawcami. Doprowadziło to również do powiększenia się liczby osób bezrobotnych na obszarach wiejskich ${ }^{34}$. Taka koncepcja jest także pewną alternatywą dla trudno osiągalnych kredytów bankowych. Przedpłatnik (w tym przypadku konsument współpracujący w ramach RWS) wpłaca sumę określoną przez wykonawcę (rolnika), następuje podział ryzyka: jeśli zbiory nie będą urodzajne, nie otrzymują oni zwrotu pieniędzy, a jedynie mniejsze paczki. Natomiast w czasie dobrych plonów rolnik „odwdzięcza” się większą liczbą produktów przy tej samej cenie. Tym samym wśród konsumentów wzrasta zainteresowanie sytuacją rolno-spożywczą oraz świadomość w zakresie rozwoju zrównoważonego ${ }^{35}$. Istnienie tych małych gospodarstw rolnych warunkuje bezpieczeństwo żywności w Polsce. Jeśli lokalna społeczność rozwinęłaby koncepcję RWS-ów na tyle, aby w jej ramach zatrudniać dodatkowe osoby, powstałaby możliwość zmniejszenia bezrobocia w ramach zielonych miejsc pracy (taka sytuacja występuje obecnie między innymi w Stanach Zjednoczonych).

Rolnictwo Wspierane przez Społeczność to nie tylko formalnie ugruntowana współpraca, ale także rozwój lokalny mieszkańców oraz popularyzacja działań na rzecz środowiska. Na przykład w USA, gdzie rozwój koncepcji RWS jest na zaawansowanym poziomie, społeczność organizuje spotkania towarzyskie w ramach tej idei, na przykład kursy gotowania, o tematyce zdrowego odżywania, a także imprezy tematyczne z zakresu ochrony środowiska. Innym zjawiskiem jest możliwość przeprowadzki na wieś oraz rozpoczęcie własnej działalności zarobkowej przez osoby, które wcześniej nie mogły zrealizować tego planu. RWS stał się więc także alternatywą dla tych, którzy chcą opuścić miasto na rzecz obszarów wiejskich ${ }^{36}$.

Jakie zagrożenia ograniczają współcześnie rozwój Rolnictwa Wspieranego przez Społeczność? Podstawą działalności w tym zakresie jest znalezienie konsumenta i przekonanie go do RWS-ów, które wiążą się z takimi wadami, jak se-

${ }^{34} \mathrm{P}$. Subotkiewicz, Rolnictwo wspierane przez spoleczność to szansa na przetrwanie matych gospodarstw rolnych, 2015, http://witrynawiejska.org.pl/przesiebiorczosc/sprzedaz-zywnosci/item/ 44701-rolnictwo-wspierane-przez-spolecznosc-to-szansa-na-przetrwanie-malych-gospodarstw-rolnych (dostęp: 3.05.2017).

${ }^{35}$ A. Rumińska, Rolnictwo Wspierane Społecznie, 2017, http://dolnoslaskosc.pl/rolnictwo-wspierane-spolecznie,1238.html (dostęp: 10.05.2017).

${ }^{36}$ S.M. Schnell, op. cit., s. 561-562. 
zonowość czy też odległość. Polski klimat nie daje możliwości uprawy niektórych warzyw i owoców przez cały rok, natomiast sklepy i międzynarodowe markety oferują ich stałą dostawę. Podobnie jest z odległością: konsumentami są często mieszkańcy miast, gdyż ludność wiejska zazwyczaj w sezonie jest samowystarczalna. Sklepy znaleźć można na każdym osiedlu/ulicy, a produkty z gospodarstw rolnych wiążą się z odbiorem w umówionym miejscu lub u rolnika. W przypadku RWS-ów konsument godzi się także na otrzymanie mniejszej paczki bez zwrotu pieniędzy w przypadku gorszych plonów. Często także rolnicy oczekują bezpłatnej pomocy ze strony konsumentów, co wiele osób uznaje za wadę RWS-ów. Dla rolników czynnikiem zniechęcającym do współpracy z konsumentami są sprawy administracyjne, takie jak oszacowanie kosztów, cen paczek, prowadzenie jasnej i regularnej komunikacji z odbiorcami dotyczącej stanu upraw, a także spotkań na początek i koniec sezonu, organizowanie odwiedzin i dowóz paczek do konsumentów ${ }^{37}$.

W Polsce świadomość dotycząca koncepcji RWS jest wciąż mała. Wiąże się to $\mathrm{z}$ ograniczonym udziałem szeroko pojętego marketingu w tych obszarach. Można to zmienić przez włączenie się samych RWS-ów do propagowania idei na terenach miejskich czy też organizowanie imprez tematycznych, które zainteresowałyby potencjalnych klientów. Takie metody są już stosowane w USA i zostały pozytywnie przyjęte ${ }^{38}$. Dobrą strategią wydaje się również współpraca gospodarstw, które mogłyby urozmaicić paczki z produktami, a także wspomóc się w kryzysowych sytuacjach. Innym rozwiązaniem, o którym wspominają sami właściciele RWS-ów, jest stworzenie programu pilotażowego wspomagającego wdrażanie tego pomysłu w miastach powiatowych albo wojewódzkich. Rozwiązanie to ułatwiłoby zakładanie RWS-ów przez pozyskanie środków zewnętrznych i zatrudnienie koordynatora do realizacji przedsięwzięcia. Jeśli taka pomoc się sprawdzi, można nadać następnie tym działaniom wymiar ogólnopolski, a koordynatorom zostaną przydzielone regiony, w ramach których będą zakładać i rozwijać RWS-y ${ }^{39}$. Innym ograniczeniem rozwoju Rolnictwa Wspieranego przez Społeczność są uwarunkowania prawne dla osób, które planują rozpocząć działalność od podstaw. Obecnie osoby, które chciałyby zakupić grunt rolny i zająć się produkcją żywności, są ograniczone na przykład przez wymóg posiadania wykształcenia związanego z rolnictwem czy też przepisy, które dają pierwszeństwo zakupu innym podmiotom ${ }^{40}$.

${ }^{37}$ J. Olszewska, P. Trzaskowski, op. cit., s. 8.

${ }^{38}$ S.M. Schnell, op. cit., s. 562.

${ }^{39}$ P. Subotkiewicz, op. cit.,

${ }^{40}$ M. Ślusarz, Kto i gdzie kupi ziemię? Ministerstwo odpowiada, 2016, http://www.strefaagro.echodnia.eu/artykul/kto-i-gdzie-kupi-ziemie-ministerstwo-odpowiada (dostęp: 15.05.2017). 


\section{Podsumowanie i wnioski}

Rolnictwo Wspierane przez Społeczność to koncepcja, która może potencjalnie rozwiązać wiele współczesnych problemów, takich jak ochrona środowiska i żywności, zapewnienie przychodów i miejsc pracy mieszkańcom wsi, utrzymanie małych gospodarstw rolnych, a nawet, w pewnym stopniu, monopolu międzynarodowych firm na rynku żywnościowym. Koncepcje zrównoważonego rozwoju oraz zielonych kołnierzyków są podstawą RWS, którego rozwój powinien być wspierany przez politykę państwa, zaangażowanie instytucji unijnych oraz rozwój sektorów związanych z zieloną gospodarką i rynku potencjalnych klientów zielonych produktów i usług ${ }^{41}$. Rolnictwo Wspierane przez Społeczność jest więc alternatywą rozwoju rolnictwa zrównoważonego przy jednoczesnym zapewnieniu zielonych miejsc pracy na obszarach wiejskich.

$\mathrm{W}$ artykule przeanalizowano podstawowe zasady, cele, ograniczenia i perspektywy rozwoju RWS-ów oraz stwierdzono, że zwiększa się zainteresowanie zdrowym trybem życia. Konsumenci chcą być bardziej świadomi tego, w jaki sposób są uprawiane produkty, które kupują. Jedną z zalet Rolnictwa Wspieranego przez Społeczność, z punktu widzenia konsumentów, jest możliwość doglądania upraw i poszerzania wiedzy o produktach rolno-żywnościowych. Dodatkowo rozwój zrównoważony wraz z zielonym rynkiem pracy należy do priorytetów Unii Europejskiej, co potwierdza nie tylko zauważalne przejście z brown economy do green economy, ale także najnowsze rozporządzenia i normy, które muszą być przestrzegane przez kraje członkowskie. UE przez swoją strategię rozwoju ma na celu polepszenie sytuacji na obszarach wiejskich i ograniczenie negatywnego wpływu na środowisko.

Monopolizacja rynku żywnościowego przyczyniła się do upadku wielu małych osiedlowych sklepów będących źródłem przychodów lokalnych, rodzinnych gospodarstw. Tym samym pogorszyła się również sytuacja polskich rolników. Możliwość nawiązania współpracy z konsumentami kupującymi produkty bezpośrednio u rolników, którzy dodatkowo wspierają rolników finansowo, przyczyni się do poprawy sytuacji wielu gospodarstw rolnych.

W USA, gdzie rozwój koncepcji Rolnictwa Wspieranego przez Społeczność jest na zaawansowanym poziomie, rozwinęło się wiele opcji dotyczących tej współpracy, a nawet model odbiegający od standardowej realizacji idei, tzw. consumer-led CSA, w którym całe zaangażowanie w rozwój i inwestycje znajduje się po stronie zrzeszonej grupy konsumentów. Polski rynek Rolnictwa Wspieranego przez Społeczność znalazł swoich zwolenników, jednakże jest on wciąż na etapie rozwoju i obecnie zgodnie z tą koncepcją działa zaledwie kilka podmiotów, mimo stałego wzrostu liczby gospodarstw ekologicznych. Bazując na amerykańskim doświadczeniu, może on nabyć odpowiedniej wiedzy, aby rozwinąć się w najbliż-

${ }^{41}$ B. Kryk, op. cit., 
szym czasie. Popularyzacja idei RWS, a także wsparcie merytoryczne i polityczno-prawne, umożliwiłyby i przyspieszyłyby jego rozwój.

RWS jest odpowiedzią na nasilające się ekologiczne oczekiwania konsumentów, polityków, a także na obawy lokalnych producentów, których działalność zależy między innymi od pogody, aktualnej sy tuacji ekonomicznej i trendów pojawiających się na rynku. Zniwelowanie niebezpieczeństw związanych z tymi aspektami przyczyniłoby się do szybszego wzrostu liczby gospodarstw ekologicznych (także tych ubiegających się o certyfikaty). Warto więc przyjrzeć się bliżej tej koncepcji, przyczyniając się tym samym do wzmocnienia rozwoju zrównoważonego.

\section{Bibliografia}

Barłowska J., Wolanciuk A., Idec J., Rolnictwo ekologiczne w Polsce na tle Unii Europejskiej i świata, „Przegląd Hodowlany” 2017, nr 2.

Brown C., Miller S., The Impact of local: a review of research on farmers markets and community supported agriculture, „American Journal of Agricultural Economics”2008, vol. 90, issue 5.

Ciobanu C., Trzaskowski P., Rolnictwo Wspierane przez Społeczność. Budując sojusz między miastem a wsia, 2017, https://cohabitat.net/blog/rolnictwo-wspierane-przez-spolecznosc-budujac-sojusz-miedzy-miastem-i-wsia (dostęp: 9.05.2017).

Jarocka M., Olszewska J., Żywność, ludzie, środowisko, IGO, Warszawa 2016.

Kryk B., Czas na zielone kotnierzyki, „Ekonomia i Środowisko” 2012, nr 3(50).

Kryk B., Relacje ekonomii społecznej z koncepcją zrównoważonego rozwoju, „Ekonomia i Środowisko" 2012, nr 3(43).

Oleszko-Kurzyna B., Rozwój zrównoważony rolnictwa wobec wymagań UE w zakresie ochrony środowiska, „Zeszyty Naukowe SGGW w Warszawie. Problemy Rolnictwa Światowego” 2008, t. 98, z. 4.

Olszewska J., Trzaskowski P., Rolnictwo Wspierane przez Społeczność, partnerstwo między rolnikami a konsumentami, IGO, Warszawa 2014.

Polska Zielona Sieć, Alternatywne systemy żywnościowe: Rolnictwo Wspierane przez Społeczność, 2014, http://dlaklimatu.pl/alternatywne-systemy-zywnosciowe-rolnictwo-wspierane-przez-spolecznosc/ (dostęp: 10.05.2017).

Radziewicz J., Rolnictwo Wspierane przez Społeczność - zdrowa żywność od rolnika, „Rolniczy Magazyn Elektroniczny" 2016, http://rme.cbr.net.pl/index.php/wiadomosci-rolnicze/573-archiwum-rme/marzec-kwiecien-nr-72/wiadomosci-rolnicze/870-rolnictwo-wspierane-przez-spolecznosc-rws-zdrowa-zywnosc-prosto-od-rolnika (dostęp: 8.05.2017).

Rumińska A., Rolnictwo Wspierane Społecznie, 2017, http://dolnoslaskosc.pl/rolnictwo-wspierane-spolecznie,1238.html (dostęp: 10.05.2017).

Rutkowska-Podołowska M., Popławski Ł., Rolnictwo a zielone miejsca pracy, ,Studia i Prace WNEiZ US" 2016, nr 44/3.

Schnell S.M., Food with a Farmer's Face: Community-Supported Agriculture in the United States, „Geographical Review” 2007, vol. 97, nr 4.

Schulz M., Oczekiwania konsumentów na rynku produktów prozdrowotnych i przyjaznych dla środowiska, „Nierówności Społeczne a Wzrost Gospodarczy” 2016, nr 45.

Subotkiewicz P., Rolnictwo wspierane przez społeczność to szansa na przetrwanie małych gospodarstw rolnych, 2015, http://witrynawiejska.org.pl/przesiebiorczosc/sprzedaz-zywnosci/item/ 44701-rolnictwo-wspierane-przez-spolecznosc-to-szansa-na-przetrwanie-malych-gospodarstw-rolnych (dostęp: 3.05.2017). 
Ślusarz M., Kto i gdzie kupi ziemię? Ministerstwo odpowiada, 2016, http://www.strefaagro.echodnia.eu/artykul/kto-i-gdzie-kupi-ziemie-ministerstwo-odpowiada (dostęp: 15.05.2017).

Ulica Ekologiczna, Locavore - myśl globalnie, jedz lokalnie, 2014, http://ulicaekologiczna.pl/kuchnia/locavore-mysl-globalnie-jedz-lokalnie (dostęp: 18.06.2017).

Ustawa z dnia 6 grudnia 2006 r. o zasadach prowadzenia polityki rozwoju (Dz.U. z 2009 r. Nr 84, poz. 712 z późn. zm.).

Wasilik K., Idea Fair Trade. W kierunku odpowiedzialnej konsumpcji, „Zeszyty Naukowe Uniwersytetu Szczecińskiego. Problemy Zarządzania, Finansów i Marketingu” 2015, nr 38.

Wspieraj Rolnictwo, RWS-y w Polsce, 2017, http://www.wspierajrolnictwo.pl/rwsy-w-polsce (dostęp: 5.05.2017).

Żmija D., Zrównoważony rozwój rolnictwa i obszarów wiejskich w Polsce, „Polityka Gospodarcza w Okresie Transformacji i Kryzysu” 2014, nr 166.

\section{Streszczenie}

Podstawowym celem pracy jest przedstawienie istoty koncepcji Rolnictwa Wspieranego przez Społeczność (RWS) przez zobrazowanie zastosowania tej idei w rozwoju zrównoważonym na obszarach wiejskich w Polsce. W artykule skoncentrowano się na przedstawieniu uwarunkowań dla rozwoju RWS oraz podano przykłady wykorzystania tej koncepcji w innych państwach. Na podstawie przeanalizowanej literatury przedmiotu, zarówno polskiej, jak i zagranicznej, przedstawiono podstawowe założenia i cele koncepcji, a także bariery rozwoju i oczekiwane rezultaty. RWS jest stosunkowo nową koncepcją na terenie Polski, jednakże jej wdrażanie może przyczynić się do rozwiązania problemu tzw. zielonych miejsc pracy oraz zdynamizowania rozwoju obszarów wiejskich przy zachowaniu troski o środowisko naturalne.

Słowa kluczowe: Rolnictwo Wspierane przez Społeczność, rozwój zrównoważony, zielone miejsca pracy

Klasyfikacja JEL: Q13 